\title{
Influence of Various Row Spacing on the Yield and Yield Components of Raya Anmol and Faisal Canola under Coastal Climatic Conditions of Lasbela
}

\author{
Muhammad Waseem ${ }^{*}$, Dost Mohammad Baloch1, Imran Khan² \\ ${ }^{1}$ Faculty of Agriculture, Lasbela University of Agriculture, Water and Marine Sciences, Uthal, Pakistan \\ ${ }^{2}$ Department of Agronomy, University of Agriculture, Faisalabad, Pakistan \\ Email: " mianwaseem 1028@yahoo.com
}

Received 8 May 2014; revised 9 June 2014; accepted 25 June 2014

Copyright (C) 2014 by authors and Scientific Research Publishing Inc.

This work is licensed under the Creative Commons Attribution International License (CC BY).

http://creativecommons.org/licenses/by/4.0/

C) (7) Open Access

\begin{abstract}
During 2013-2014 a field experiment was conducted at experimental area of Faculty of Agriculture under Lasbela University of Agriculture, Water and Marine Science, Uthal, Lasbela to evaluate the influence of various row spacing on the yield and yield components of Raya Anmol and Faisal Canola under coastal climatic conditions of Lasbela. Randomized complete block design (RCBD) with factorial arrangement having 3 replications was used. Experiment comprises two canola varieties, $C_{1}=$ Raya Anmol, $C_{2}=$ Faisal Canola at 3 row spacing distances $R S_{1}=30 \mathrm{~cm}, R_{2}=45 \mathrm{~cm}$ and $\mathrm{RS}_{3}=60 \mathrm{~cm}$ respectively. Result showed that yield and yield contributing traits are significant. It was concluded that seed yield of $C_{1}$ (Faisal Canola) was better as compared to that of Raya Anmol. Row spacing $\left(\mathrm{RS}_{3}=60 \mathrm{~cm}\right)$ yielded more crop canopy and the highest number of pod per plant, pod length and seed yield under agro climatic condition of Lasbela as compared to other densely arranged row spacing.
\end{abstract}

\section{Keywords}

Canola, Cultivar, Row Spacing, Coastal Environment

\section{Introduction}

Canola cultivation comes under the conventional oil seed crop in Pakistan. Pakistan pays a large foreign exchange on the import of edible oil for own consumption which is increasing with the passage of time. The major

${ }^{*}$ Corresponding author.

How to cite this paper: Waseem, M., Baloch, D.M. and Khan, I. (2014) Influence of Various Row Spacing on the Yield and Yield Components of Raya Anmol and Faisal Canola under Coastal Climatic Conditions of Lasbela. American Journal of Plant Sciences, 5, 2230-2236. http://dx.doi.org/10.4236/ajps.2014.515237 
oilseed crops include cottonseed, sunflower, canola and rapeseed/mustard. Local production of edible oil is remained 0.636 million tonnes while imports were 2.148 million. During the year 2012-2013 (July-March), 1.738 million tonnes of edible oil valued at Rs. 153.3 billion (US $\$ 1.595$ billion) have been imported. The local production during 2012-2013 (July-March) was 0.612 million tonnes. Total availability of edible oil from all sources is provisionally estimated at 2.35 million tonnes during 2012-2013 (July-March). The contribution of rapeseed and canola in term of area is 0.482 million hac with a production of 176 million tonnes' seeds [1].

Rape seed and mustard are the $2^{\text {nd }}$ most important edible source of oil after cotton seed, but quality of oil obtained is inferior due to the presence of high content of erucic acid and glucosinolates in oil. New developed canola cultivars with low erucic acid and glucosinolates made the canola oil highly valuable. Cholesterol level in canola oil is very low as compared to other. Improved canola or hybrids are capable to produce higher yields when it was grown under optimum agronomic practices.

Plants cultivated in wider rows may not properly utilize the natural resources such as light, water and nutrients, whereas growing in narrower rows may result in different ways [2].

Christensen and Drabble observed that narrower row produced better result as compared to in wider row in case of B. napus or B. rapa. The establishment of an adequate and uniform canola stand is critical to achieve high grain yield.

Boundary of lasbela is directly touched to Arabian Sea and has an approximately $300 \mathrm{~km}$ coastal area along the sea. It is very hot during May and June, and gets cold during the December and January. The rainy season is mostly in July and August. Geographically, the district can be divided into the alluvial plain surrounding Lasbela extending southwards upto the Bay of Sonmiani and the hilly regions situated in the east and west of this plain. The plain itself consists of alluvium deposits of Porali and other rivers. At the edge of the plain there are adjoining hilly regions and near the coast, lying raised sea-beaches, situated some 15 to 25 meters above the sea level. The botanical feature of Raya Anmol and Faisal Canola is that plant height is equal in both varieties but other yield contributing traits differ from each other. Raya Anmol and Faisal Canola locally produced varieties of Pakistan according to its climatic condition.

Seed yield of canola is a function of planting geometry which is very plastic and adjustable across a wide range of population [3]. Therefore, it is of crucially importance about how to manipulate the row spacing in order to increase plant productivity.

\section{Material and Method}

A field experiment was conducted at experimental area of Faculty of Agriculture to evaluate the influence of various row spacing on the yield and yield components of Raya Anmol and Faisal Canola under coastal climatic conditions of Lasbela. Experiment was laid out under randomized complete block design (RCBD) with factorial arrangement having 3 replications with net plot size of $1.8 \mathrm{~m} \times 2 \mathrm{~m}$ was used. Experiment were comprises two canola varieties; $\mathrm{C}_{1}=$ Raya Anmol, $\mathrm{C}_{2}=$ Faisal Canola at 3 row spacing distances $\mathrm{RS}_{1}=30 \mathrm{~cm}, \mathrm{RS}_{2}=45 \mathrm{~cm}$ and $\mathrm{RS}_{3}=60 \mathrm{~cm}$ respectively. Recommended fertilizer rates $75-50 \mathrm{~kg} \cdot \mathrm{ha}^{-1} \mathrm{NP}$ was used respectively. Half of $\mathrm{N}$ and full dose of $\mathrm{P}$ were applied as a basal dose while the remaining half $\mathrm{N}$ was applied at flowering. Nitrogen and phosphorus were used in the form of urea and DAP respectively. The crop was sown on Nov, 2013 using a seed rate of $5 \mathrm{~kg} \mathrm{ha}^{-1}$ and harvested on March 25, 2014. All agronomic practices like plant population, number of irrigations, and plant protection measure etc. were kept uniform and normal for all other treatments. Following parameter like plant height, pod length, number of pod per plant, number of seed per pod and seed yield were recorded and analyzed statistically using Fisher's analysis of variance technique and LSD test at 5\% probability was used to compare the differences among treatments means [4]. Weather data 2013-2014 during the crop season was given in Table A1.

\section{Results and Discussion}

\subsection{Plant Height at Maturity (cm)}

Plant height is directly affected by genetic traits and environmental characteristics. In plant height was significantly influenced by Raya Anmol and Faisal Canola. The data in (Table 1) shows $\mathrm{C}_{2}$ produced maximum plant height as compared $\mathrm{C}_{1}$. Same results were reported by [5]-[9].

In case of row spacing $\mathrm{RS}_{3}$ was give maximum plant height while minimum plant height was found in $\mathrm{RS}_{1}$ and was significantly different. These results are in agreement with the findings of [5]-[7]. 
Table 1. Effect of Faisal Canola and Raya Anmol varieties and different row spacing on plant height at maturity (cm).

\begin{tabular}{ll}
\hline Treatments & Plant height (cm) \\
\hline A) Varieties & \\
$\mathrm{C}_{1}=$ Raya Anmol & $96^{\mathrm{b}}$ \\
$\mathrm{C}_{2}=$ Faisal Canola & $110^{\mathrm{a}}$ \\
B) $\quad$ Row spacing & \\
$\mathrm{RS}_{1}=30 \mathrm{~cm}$ & $91^{\mathrm{c}}$ \\
$\mathrm{RS}_{2}=45 \mathrm{~cm}$ & $99^{\mathrm{b}}$ \\
$\mathrm{RS}_{3}=60 \mathrm{~cm}$ & $105^{\mathrm{a}}$ \\
$\mathrm{C} \quad$ Interaction (varieties $\times$ row spacing) & \\
$\mathrm{C}_{1} \mathrm{RS}_{1}$ & $85^{\mathrm{d}}$ \\
$\mathrm{C}_{1} \mathrm{RS}_{2}$ & $89^{\mathrm{d}}$ \\
$\mathrm{C}_{1} \mathrm{RS}_{3}$ & $90^{\mathrm{c}}$ \\
$\mathrm{C}_{2} \mathrm{RS}_{1}$ & $100^{\mathrm{b}}$ \\
$\mathrm{C}_{2} \mathrm{RS}_{2}$ & $103^{\mathrm{b}}$ \\
$\mathrm{C}_{2} \mathrm{RS}_{3}$ & $112^{\mathrm{a}}$ \\
\hline
\end{tabular}

Mean values in column not having the same letter vary significantly at $\mathrm{P}=0.05$.

Humidity is low in mostly coastal area of the world and Temperature mostly range deviate very little from normal range in cropping season.

An interactive effect between rapeseed varieties and row spacing was statistically significant.

\subsection{Pod Length (cm)}

Table 2 showed that pod length is directly control by genetic traits. Pod length was significantly influenced by Raya Anmol and Faisal Canola. $\mathrm{C}_{2}$ (Faisal canola) produced maximum pod length as compared $\mathrm{C}_{1}$. Same results were reported by [10]-[12].

Effect of row spacing on pod length was also observed significant. In case of row spacing $\mathrm{RS}_{3}$ was give maximum pod length while minimum pod length was found in $\mathrm{RS}_{1}$ and was significantly different. These results are in opposite to the findings of [10]. Interactive effect between rapeseed varieties and row spacing was statistically significant.

\subsection{Number of Pod per Plant}

Number of pod per plant is directly affected the yield. Number of pod per plant was significantly influenced by Raya Anmol and Faisal Canola. Data in (Table 3) shows that $\mathrm{C}_{2}$ produced maximum number of pod per plant as compared $\mathrm{C}_{1}$. Similar results were reported by [3] and [13].

A for as row spacing $\mathrm{RS}_{3}$ was give maximum number of pod per plant while minimum number of pod per plant was found in $\mathrm{RS}_{1}$ and was significantly different from each other as showed in table. These results are in closely related with the findings of [8] [10].

An interactive effect between rapeseed varieties and row spacing was statistically significant. Maximum interactive effect was observed for $\mathrm{C}_{2} \mathrm{RS}_{3}$ as compared to other treatment.

\subsection{Number of Seed per Pod}

Number of seed per pod statistically significant. Table 4 showed that number of seed per pod was significantly influenced by Raya Anmol and Faisal Canola. It was found that $C_{2}$ produced maximum number of seed per pod as compared $\mathrm{C}_{1}$. These result are lined with [8] and [14]-[16]. 
Table 2. Effect of Faisal Canola and Raya Anmol varieties and different row spacing on pod length.

\begin{tabular}{ll}
\hline Treatments & Pod length \\
\hline A) Varieties & \\
$\mathrm{C}_{1}=$ Raya Anmol & $4^{\mathrm{b}}$ \\
$\mathrm{C}_{2}=$ Faisal Canola & $7^{\mathrm{a}}$ \\
B) $\quad$ Row spacing & \\
$\mathrm{RS}_{1}=30 \mathrm{~cm}$ & $5^{\mathrm{b}}$ \\
$\mathrm{RS}_{2}=45 \mathrm{~cm}$ & $7^{\mathrm{a}}$ \\
$\mathrm{RS}_{3}=60 \mathrm{~cm}$ & $8^{\mathrm{a}}$ \\
$\mathrm{C} \quad$ Interaction (varieties $\times$ row spacing) & \\
$\mathrm{C}_{1} \mathrm{RS}_{1}$ & $4^{\mathrm{c}}$ \\
$\mathrm{C}_{1} \mathrm{RS}_{2}$ & $4^{\mathrm{c}}$ \\
$\mathrm{C}_{1} \mathrm{RS}_{3}$ & $5^{\mathrm{c}}$ \\
$\mathrm{C}_{2} \mathrm{RS}_{1}$ & $6^{\mathrm{b}}$ \\
$\mathrm{C}_{2} \mathrm{RS}_{2}$ & $7^{\mathrm{b}}$ \\
$\mathrm{C}_{2} \mathrm{RS}_{3}$ & $9^{\mathrm{a}}$ \\
\hline
\end{tabular}

Mean values in column not having the same letter vary significantly at $\mathrm{P}=0.05$.

Table 3. Effect of Faisal Canola and Raya Anmol varieties and different row spacing on number of pod per plant.

\begin{tabular}{|c|c|}
\hline Treatments & Pod per plant \\
\hline A) Varieties & \\
\hline $\mathrm{C}_{1}=$ Raya Anmol & $356^{\mathrm{b}}$ \\
\hline $\mathrm{C}_{2}=$ Faisal Canola & $386^{\mathrm{a}}$ \\
\hline B) Row spacing & \\
\hline $\mathrm{RS}_{1}=30 \mathrm{~cm}$ & $300^{\mathrm{b}}$ \\
\hline $\mathrm{RS}_{2}=45 \mathrm{~cm}$ & $326^{\mathrm{b}}$ \\
\hline $\mathrm{RS}_{3}=60 \mathrm{~cm}$ & $381^{\mathrm{a}}$ \\
\hline C) Interaction (varieties $\times$ row spacing) & \\
\hline $\mathrm{C}_{1} \mathrm{RS}_{1}$ & $305^{\mathrm{d}}$ \\
\hline $\mathrm{C}_{1} \mathrm{RS}_{2}$ & $296^{\mathrm{d}}$ \\
\hline $\mathrm{C}_{1} \mathrm{RS}_{3}$ & $315^{c}$ \\
\hline $\mathrm{C}_{2} \mathrm{RS}_{1}$ & $348^{\mathrm{b}}$ \\
\hline $\mathrm{C}_{2} \mathrm{RS}_{2}$ & $345^{\mathrm{b}}$ \\
\hline $\mathrm{C}_{2} \mathrm{RS}_{3}$ & $363^{\mathrm{a}}$ \\
\hline
\end{tabular}

Mean values in column not having the same letter vary significantly at $\mathrm{P}=0.05$.

On the other hand row spacing $\mathrm{RS}_{3}$ was give maximum number of seed per pod while minimum number of seed per pod was found in $\mathrm{RS}_{1}$ and was significantly different from each other as showed in table. These results are correlated with the findings of [14] and [15].

An interactive effect between rapeseed varieties and row spacing was statistically significant. Maximum interactive effect was observed for $\mathrm{C}_{2} \mathrm{RS}_{3}$ as compared to other treatment.

\subsection{Seed Yield}

Seed yield is cumulative sum of number of pod per plant, number of seed per pod and pod length. Seed yield 
was statistically significant and observed that number of seed yield was significantly influenced by Raya Anmol and Faisal Canola. It was found that $\mathrm{C}_{2}$ produced maximum number of seed yield as compared $\mathrm{C}_{1}$. These results are lined with [2] [3] [14] [15] [17].

In interaction row spacing $\mathrm{RS}_{3}$ was give maximum number of seed yield while minimum seed yield was found in $\mathrm{RS}_{1}$ and was significantly different from each other as showed in Table 5. These results are correlated with the findings of [2] and [17].

An interactive effect between rapeseed varieties and row spacing was statistically significant. Maximum interactive effect was observed for $\mathrm{C}_{2} \mathrm{RS}_{3}$ as compared to other treatment.

Table 4. Effect of Faisal Canola and Raya Anmol varieties and different row spacing on number of seed per pod.

\begin{tabular}{ll}
\hline Treatments & Number of seed per pod \\
\hline A) $\quad$ Varieties & \\
$\mathrm{C}_{1}=$ Raya Anmol & $20^{\mathrm{b}}$ \\
$\mathrm{C}_{2}=$ Faisal Canola & $28^{\mathrm{a}}$ \\
B) Row spacing & \\
$\mathrm{RS}_{1}=30 \mathrm{~cm}$ & $19^{\mathrm{c}}$ \\
$\mathrm{RS}_{2}=45 \mathrm{~cm}$ & $23^{\mathrm{b}}$ \\
$\mathrm{RS}_{3}=60 \mathrm{~cm}$ & $27^{\mathrm{a}}$ \\
$\mathrm{C}) \quad$ Interaction (varieties $\times$ row spacing) & \\
$\mathrm{C}_{1} \mathrm{RS}_{1}$ & $18^{\mathrm{c}}$ \\
$\mathrm{C}_{1} \mathrm{RS}_{2}$ & $20^{\mathrm{c}}$ \\
$\mathrm{C}_{1} \mathrm{RS}_{3}$ & $26^{\mathrm{b}}$ \\
$\mathrm{C}_{2} \mathrm{RS}_{1}$ & $27^{\mathrm{b}}$ \\
$\mathrm{C}_{2} \mathrm{RS}_{2}$ & $29^{\mathrm{a}}$ \\
$\mathrm{C}_{2} \mathrm{RS}_{3}$ & $30^{\mathrm{a}}$ \\
\hline
\end{tabular}

Mean values in column not having the same letter vary significantly at $\mathrm{P}=0.05$.

Table 5. Effect of Faisal Canola and Raya anmol varieties and different row spacing on seed yield.

\begin{tabular}{|c|c|}
\hline Treatments & Seed yield $\left(\mathrm{kg} \cdot \mathrm{ha}^{-1}\right)$ \\
\hline \multicolumn{2}{|l|}{ A) Varieties } \\
\hline $\mathrm{C}_{1}=$ Raya Anmol & $2996^{b}$ \\
\hline $\mathrm{C}_{2}=$ Faisal Canola & $3456^{\mathrm{a}}$ \\
\hline \multicolumn{2}{|l|}{ B) Row spacing } \\
\hline $\mathrm{RS}_{1}=30 \mathrm{~cm}$ & $3256^{c}$ \\
\hline $\mathrm{RS}_{2}=45 \mathrm{~cm}$ & $3301^{\mathrm{b}}$ \\
\hline $\mathrm{RS}_{3}=60 \mathrm{~cm}$ & $3325^{\mathrm{a}}$ \\
\hline \multicolumn{2}{|c|}{ C) Interaction (varieties $\times$ row spacing) } \\
\hline $\mathrm{C}_{1} \mathrm{RS}_{1}$ & $3002^{\mathrm{c}}$ \\
\hline $\mathrm{C}_{1} \mathrm{RS}_{2}$ & $2953^{c}$ \\
\hline $\mathrm{C}_{1} \mathrm{RS}_{3}$ & $2856^{\mathrm{c}}$ \\
\hline $\mathrm{C}_{2} \mathrm{RS}_{1}$ & $3306^{\mathrm{a}}$ \\
\hline $\mathrm{C}_{2} \mathrm{RS}_{2}$ & $3205^{b}$ \\
\hline $\mathrm{C}_{2} \mathrm{RS}_{3}$ & $3376^{\mathrm{a}}$ \\
\hline
\end{tabular}

Mean values in column not having the same letter vary significantly at $\mathrm{P}=0.05$. 


\section{Conclusion}

On the basis of finding it was concluded that cultivation of crops in coastal climate favored the yield of canola because humidity was low and the temperature mostly deviated very little from normal sequence in cropping season. Seed yield of $\mathrm{C}_{1}$ (Faisal Canola) was better as compared to that of Raya Anmol. Wider row spacing (RS ${ }_{3}$ $=60 \mathrm{~cm}$ ) yielded more crop canopy and the highest number of pod per plant, pod length and seed yield under agro climatic condition of Lasbela as compared to other densely arranged row spacing.

\section{References}

[1] Government of Pakistan (2012-13) Economic Survey of Pakistan. Government of Pakistan, Finance and Economic Affairs Division, Islamabad, 21.

[2] Ali, Y., Ahsanul Hag, M., Tahir, G.R. and Ahmad, N. (1999) Effect of Inter and Intra Row Spacing on the Yield and Yield Components of Chickpea. Pakistan Journal of Biological Sciences, 2, 305-307. http://dx.doi.org/10.3923/pjbs.1999.305.307

[3] Diepenbrock, W. (2000) Yield Analysis of Winter Oilseed Rape (Brassica napus L.): A Review. Field Crops Research, 67, 35-49. http://dx.doi.org/10.1016/S0378-4290(00)00082-4

[4] Steel, R.G.D., Torrie, J.H. and Dicky, D.A. (1997) Principles and Procedures of Statistics. A Biometrical Approach. 3rd Edition, McGraw Hill Book Co. Inc., New York, 400-428.

[5] Van Deynze, A.E., McVetty, P.B.E., Scarth, R. and Rimmer, R.S. (1995) Effect of Varying Seeding Rates on Hybrid and Conventional Summer Rape Performance in Manitoba. Canadian Journal of Plant Science, 72, 635-641. http://dx.doi.org/10.4141/cjps92-079

[6] Zang, P.H. and Sedum, P.J. (1995) Interactions among Phosphorous, Nitrogen and Growth in Oil Seed Rape. Canadian Journal of Plant Science, 74, 173-181.

[7] Starner, D.E., Hamama, A.A. and Bhardwaj, L. (1999) Canola Oil Yield and Quality as Affected by Production Practices in Virginia. In: Janick, J., Ed., Perspectives on New Crops and New Uses, ASHS Press, Alexandria, 254-256.

[8] Bybordi, A., Tabatabaei, S.J. and Ahmedov, A. (2010) Effects of Salinity on Fatty Acid Composition of Canola (Brassica napus L.). Journal of Food Agriculture and Environment, 8, 113-115.

[9] Saglam, C., Bayhan, Y., Gonulol, E. and Ulger, P. (2009) Economic Aspect of Soil Tillage Systems in Canola Farming. Bulgarian Journal of Agricultural Science, 15, 237-242.

[10] Francois, L.E. (1994) Growth, Seed Yield, and Oil Content of Canola Grown under Saline Conditions. Agronomy Journal, 86, 233-237. http://dx.doi.org/10.2134/agronj1994.00021962008600020004x

[11] Uzun, B., Zengin, U., Furat, S. and Akdesir, O. (2009) Sowing Date Effects on Growth, Flowering, Oil Content and Seed Yield of Canola Cultivars. Asian Journal of Chemistry, 21, 1957-1965.

[12] Bybordi, A., Tabatabaei, S.J. and Ahmedov, A. (2010) Effects of Salinity on Fatty Acid Composition of Canola (Brassica napus L.). Journal of Food Agriculture and Environment, 8, 113-115.

[13] Hussain, I., Ayyaz Khan, M. and Ahmad, K. (2003) Effect of Row Spacing on Grain Yield and the Yield Components of Wheat (Triticum aestivum L.). Pakistan Journal of Agronomy, 2, 153-159. http://dx.doi.org/10.3923/ja.2003.153.159

[14] Christensen, J.V. and Drabble, J.C. (1984) Effect of Row Spacing and Seeding Rate on Rapeseed Yield in Northwest Alberta. Canadian Journal of Plant Science, 64, 1011-1013. http://dx.doi.org/10.4141/cjps84-137

[15] Degenhardt, D.F. and Kondra, Z.P. (1981) The Influence of Seeding Date and Seeding Rate on Seed Yield and Yield Components of Five Genotypes of Brassica napus. Canadian Journal of Plant Science, 61, 175-183. http://dx.doi.org/10.4141/cjps81-027

[16] Shahin, Y. and Valiollah, R. (2009) Effects of Row Spacing and Seeding Rates on Some Agronomical Traits of Spring Canola (Brassica napus L.) Cultivars. Journal of Central European Agriculture, 10, 115-122.

[17] Bilgili, U., Sincik, M., Uzan, A. and Acikgoz, E. (2003) The Influence of Row Spacing and Seeding Rate on Seed Yield and Yield Components of Forage Turnip (Brassica napus L.). Journal of Agronomy and Crop Science, 189, 250254. http://dx.doi.org/10.1046/j.1439-037X.2003.00037.x 


\section{Appendix}

Table A1. Weather data of 2013-2014 during crop season.

\begin{tabular}{|c|c|c|c|c|c|c|c|c|c|c|c|c|c|c|c|}
\hline \multirow[b]{2}{*}{ Days } & \multicolumn{3}{|c|}{ November, 2013} & \multicolumn{3}{|c|}{ December, 2013} & \multicolumn{3}{|c|}{ January, 2014} & \multicolumn{3}{|c|}{ Februry, 2014} & \multicolumn{3}{|c|}{ March, 2014} \\
\hline & $\begin{array}{c}\text { Rainfall } \\
\text { (mm) }\end{array}$ & $\begin{array}{l}\text { Temp } \\
\max { }^{\circ} \mathrm{C}\end{array}$ & $\begin{array}{l}\text { Temp } \\
\text { mini }{ }^{\circ} \mathrm{C}\end{array}$ & $\begin{array}{c}\text { Rainfall } \\
\text { (mm) }\end{array}$ & $\begin{array}{l}\text { Temp } \\
\max ^{\circ} \mathbf{C}\end{array}$ & $\begin{array}{l}\text { Temp } \\
\text { mini }{ }^{\circ} \mathrm{C}\end{array}$ & $\begin{array}{c}\text { Rainfall } \\
(\mathrm{mm})\end{array}$ & $\begin{array}{l}\text { Temp } \\
\max { }^{\circ} \mathrm{C}\end{array}$ & $\begin{array}{c}\text { Temp I } \\
\text { mini }{ }^{\circ} \mathrm{C}\end{array}$ & $\begin{array}{c}\text { Rainfall } \\
\text { (mm) }\end{array}$ & $\begin{array}{l}\text { Temp } \\
\max { }^{\circ} \mathrm{C}\end{array}$ & Temp & $\begin{array}{c}\text { Rainfall } \\
\quad(\mathrm{mm})\end{array}$ & $\begin{array}{l}\text { Temp } \\
\max { }^{\circ} \mathrm{C}\end{array}$ & $\begin{array}{l}\text { Temp } \\
\text { mini }{ }^{\circ} \mathrm{C}\end{array}$ \\
\hline 1 & 0 & 36.5 & 18.5 & 0 & 31.5 & 14 & 0 & 23.2 & 1.5 & 0 & 28 & 14 & 0 & 29 & 10 \\
\hline 2 & 0 & 35 & 18.5 & 0 & 33 & 13 & 0 & 24.5 & 2.2 & 0 & 27.5 & 15 & 0 & 29 & 15 \\
\hline 3 & 0 & 34 & 18 & 0 & 33 & 12 & 0 & 25.5 & 2.5 & 0 & 28.5 & 14.5 & 0 & 25 & 14 \\
\hline 4 & 0 & 34 & 17.5 & 0 & 32 & 12.5 & 0 & 26.5 & 4.5 & 0 & 28.5 & 13.5 & 0 & 27 & 14.5 \\
\hline 5 & 0 & 37.5 & 17 & 0 & 36 & 13 & 0 & 26 & 7 & 0 & 28 & 16 & 0 & 30 & 16 \\
\hline 6 & 1.6 & 33.5 & 17 & 0 & 30.5 & 12 & 0 & 25 & 7 & 0 & 28 & 16 & 0 & 30 & 14.5 \\
\hline 7 & 0 & 31.5 & 18.5 & 0 & 30 & 14 & 0 & 27 & 7 & 0 & 23.5 & 12.5 & 0 & 32.5 & 15.5 \\
\hline 8 & 0 & 31 & 18.5 & 0 & 31 & 16 & 0 & 24 & 9.5 & 0 & 26 & 8.5 & 0 & 34 & 15.5 \\
\hline 9 & 0 & 30 & 17.5 & 0 & 29 & 16.5 & 0 & 27 & 8.5 & 0 & 26 & 9.5 & 0 & 34 & 15.5 \\
\hline 10 & 0 & 30 & 17 & 0 & 29 & 14 & 0 & 24 & 7.5 & 0 & 26.5 & 10.5 & 0 & 33.5 & 15.5 \\
\hline 11 & 0 & 30.5 & 17 & 0 & 29.5 & 13.5 & 0 & 24 & 6.5 & 0 & 26 & 8 & 0 & 30.5 & 16.5 \\
\hline 12 & 0 & 31 & 16 & 0 & 30.5 & 15 & 0 & 25 & 6.5 & 0 & 25 & 7 & 0 & 31 & 12 \\
\hline 13 & 0 & 31.5 & 17.5 & 0 & 30.5 & 13.5 & 0 & 25 & 12 & 0 & 26 & 9 & 0 & 33.5 & 15.5 \\
\hline 14 & 0 & 32.5 & 17 & 0 & 31 & 12.5 & 0 & 25 & 11.5 & 0 & 28.5 & 8.5 & 0 & 32.5 & 16 \\
\hline 15 & 0 & 31 & 15 & 0 & 30.5 & 13.5 & 0 & 25 & 10.5 & 0 & 26.5 & 11 & 0 & 34.5 & 17.5 \\
\hline 16 & 0 & 33 & 14 & 0 & 29.5 & 14.5 & 0 & 27 & 10.5 & 0 & 29 & 7 & 0 & 33.5 & 17.5 \\
\hline 17 & 0 & 30.5 & 15 & 0 & 31.5 & 15 & 0 & 27.5 & 11.5 & 0 & 29 & 8 & 0 & 17 & 33.5 \\
\hline 18 & 0 & 33 & 16 & 0 & 29 & 15.5 & 0 & 28.5 & 10 & 0 & 29 & 9 & 0 & 34.5 & 15.5 \\
\hline 19 & 0 & 32 & 15 & 0 & 28 & 12 & 0 & 25.5 & 12 & 0 & 27 & 10.5 & 0 & 34 & 15.5 \\
\hline 20 & 0 & 34 & 15.5 & 0 & 28 & 9 & 0 & 25.5 & 8 & 0 & 30.5 & 14 & 0 & 34.5 & 14.5 \\
\hline 21 & 0 & 34.5 & 16 & 0 & 27.5 & 12 & 0 & 26.5 & 4.5 & 0 & 28 & 16 & 0 & 33 & 16 \\
\hline 22 & 0 & 33 & 16 & 0 & 25 & 11 & 0 & 26 & 7 & 0 & 28 & 16 & 0 & 33.5 & 17 \\
\hline 23 & 0 & 33 & 17.5 & 0 & 26.5 & 8.5 & 0 & 25 & 7 & 0 & 23.5 & 12.5 & 0 & 30.5 & 20 \\
\hline 24 & 0 & 32 & 16.5 & 0 & 25.5 & 9.5 & 0 & 27 & 7 & 0 & 26 & 8.5 & 0 & 31.5 & 16.5 \\
\hline 25 & 0 & 32.5 & 16 & 0 & 24.5 & 10 & 0 & 24 & 9.5 & 0 & 26 & 9.5 & 0 & 32.5 & 12.5 \\
\hline 26 & 0 & 32.5 & 16 & 0 & 24.5 & 5.5 & 0 & 27 & 8.5 & 0 & 26.5 & 10.5 & 0 & 30 & 17 \\
\hline 27 & 0 & 31.5 & 16 & 0 & 25 & 4.5 & 0 & 24 & 7.5 & 0 & 26 & 8 & 0 & 32 & 14 \\
\hline 28 & 0 & 32.5 & 15.5 & 0 & 24.5 & 5 & 0 & 24 & 6.5 & 0 & 28 & 16 & 0 & 34 & 19 \\
\hline 29 & 0 & 32.5 & 16.5 & 0 & 26 & 5.5 & 0 & 25 & 6.5 & & & & 0 & 34 & 18 \\
\hline 30 & 0 & 32.5 & 15 & 0 & 25 & 6.5 & 0 & 25 & 6.5 & & & & 0 & 35 & 19.5 \\
\hline 31 & & & & 0 & 24.5 & 0 & 0 & 26 & 9.5 & & & & 0 & 35.5 & 19 \\
\hline
\end{tabular}


Scientific Research Publishing (SCIRP) is one of the largest Open Access journal publishers. It is currently publishing more than 200 open access, online, peer-reviewed journals covering a wide range of academic disciplines. SCIRP serves the worldwide academic communities and contributes to the progress and application of science with its publication.

Other selected journals from SCIRP are listed as below. Submit your manuscript to us via either submit@scirp.org or Online Submission Portal.
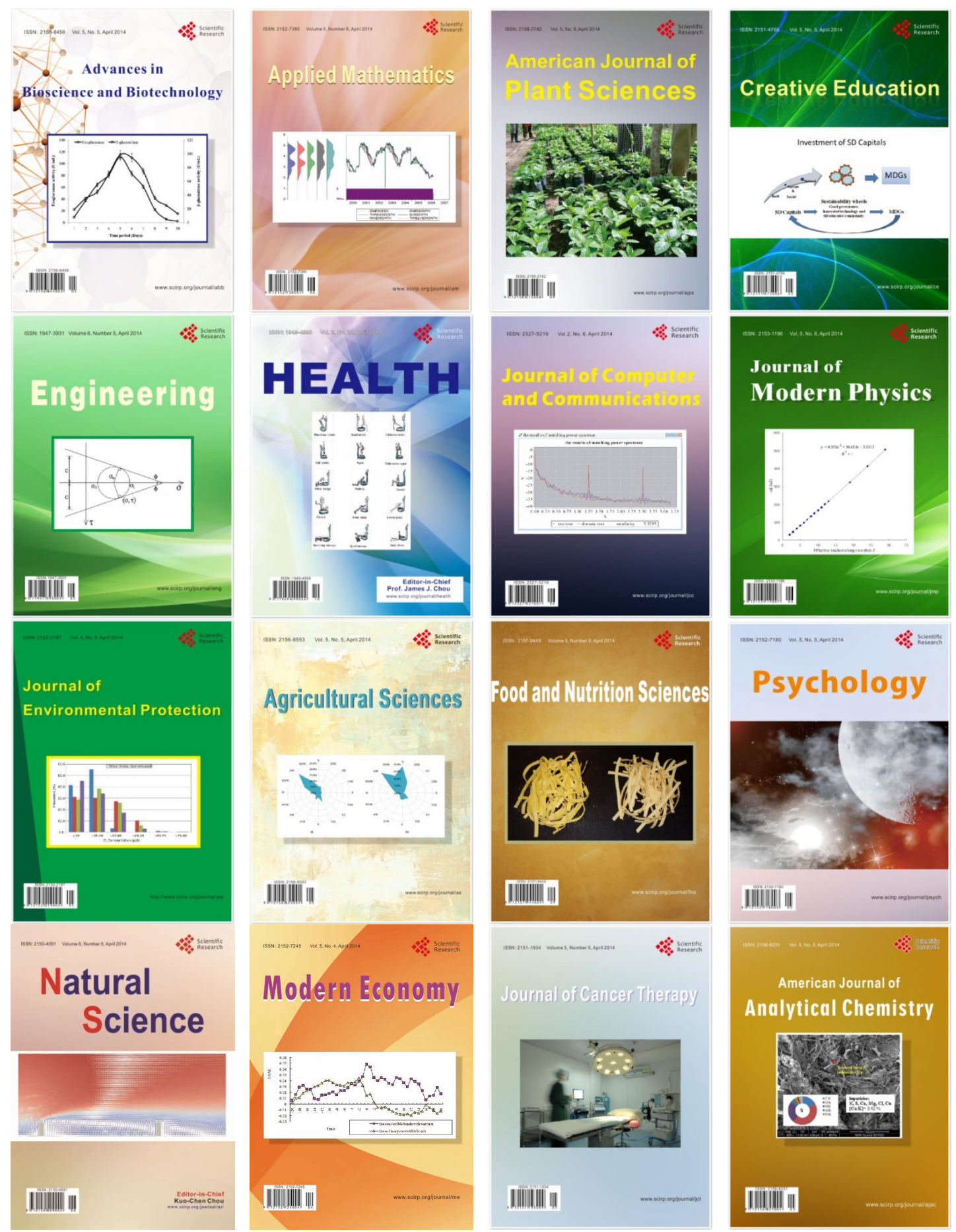